\title{
PHOTOSYNTHETIC ACTIVITY IN RELATION TO FODDER BEET PRODUCTIVITY WITH DIFFERENT PLANTING METHODS AND DENSITIES UNDER SANDY SOIL CONDITIONS
}

\author{
Eman I. El-Sarag* \\ Fac. Environ. Agric. Sci., Arish Univ., Egypt
}

\begin{abstract}
Fodder beet could be cultivated under varied environmental conditions; their yield and stomatal conductance differ according to planting methods and densities. So, two planting methods (transplanting, T. and direct seeds, Ds.) under six planting densities (33.6, 28.0, 24.0, 21.0, 18.6, 16.8 thousand plants fad $^{-1}$ ) were investigated on fodder beet (Beta vulgaris L.) at sandy soil (70\% sand) of the Experimental Farm of the Faculty of Environmental Agricultural Sciences, Arish Univ., Egypt, during 2012/2013 and 2013/2014 seasons. The experimental design was randomized complete block (RCBD) in a split plot design with three replications. The main plots were chosen for planting methods, while, the sub-plots were devoted for planting densities. Drip irrigation system was used with saline ground water (3500 ppm) pumped from a local well. Results showed that stomatal conductance (Sc.) and transpiration rate (Tr.) of upper leaves were -almost 4 times- higher than lower ones. The maximum value of Sc was achieved by T. with planting density of 28000 and by Ds. with 21000 plants fad. ${ }^{-1}$ with means of 0.31 and $0.30 \mathrm{~ms}^{-1}$, while, T. and Ds. with 28000 plants fad. ${ }^{-1}$ gave the highest Tr. with mean values of 15.41 and $14.08 \mu \mathrm{g} \mathrm{cm}^{-1} \mathrm{~s}^{-1}$. Direct seeds with planting density of 21000 plants fad $^{-1}$ gave the highest leaf, root and total yields (14.8, 136.0, 150.9 ton fad..$^{-1}$, respectively) in combined analysis. There were high positive correlation with the high total fresh yield and each of root length, diameter and new leaves Tr., where these correlation coefficient rates were $0.829^{* *}, 0.699^{*}$ and $0.569^{*}$, respectively. Also, this investigation give chemical composition of fodder beet roots grown in sandy soil under two seasons which recorded crude protein ranged between 13.6 and $11.0 \%$ and average of crude fiber of $5.6 \%$. The results suggest that root length and diameter as well as new leaves transpired could be important parameters for improving fodder beet productivity under sandy soil conditions at North Sinai Governorate and similar areas.
\end{abstract}

Key words: Fodder beet, planting methods, planting densities, line spaces, top and root fresh yield, simple correlation coefficient, chemical analyses.

\section{INTRODUCTION}

Fodder beet (Beta vulgaris L.) is valuable source of fodder for cattle (Niazi et al., 2000). According to its high content of water and sugar, it increases milk production and suitable forage for dairy cows (Hussein and Siam, 2014). Fodder beet can fulfill economic target of maximizing the benefit of sandy soils in concern to its high content of carbohydrates and high top and root fresh yields besides it could be stored for 3 months as silage (Keogh et al., 2008). In Egypt, there are many forage crops which can be successfully grown during winter season in old lands of Delta and Valley, but their area is still very small because of severe competition with other cash and food crops. Therefore, the newly reclaimed lands, such as North Sinai, which its soil is characterized as sandy soil, are the main way for maximizing the horizontal and vertical benefits of such crops besides the important role of these crops for soil building and improvement

*Corresponding author: Tel. : +201066344310

E-mail address: yasser_moselhy@yahoo.com 
during the early period of new land cultivation. Fodder beet is also, a very promising winter crop to be grown on such new reclaimed lands because of its wide adaptability to ecological conditions.

The rate of photosynthetic $\mathrm{CO}_{2}$ assimilation is generally reduced under low water and soil fertility in new reclaimed lands as it is partly due to low stomatal conductance which lead to restriction the availability of $\mathrm{CO}_{2}$ for carboxylation (Brugnoli and Lauteri, 1991). Physiological changes (stomatal conductance, transpiration rate, water and osmotic potentials) under low fertility of sandy soils and high salinity of irrigation water could be effective criteria for resistant screening and maximizing in plant breeding programs and agronomic aspects (Ashraf and Harris, 2004; Parida and Das, 2005; Ashraf and Foolad, 2007; Cha-um and Kirdmanee, 2009; Kusvuran, 2012). Stomatal response to various environments has complex mechanisms influenced by many factors; $\mathrm{H}_{2} \mathrm{O}$ vapor and gradients $\mathrm{CO}_{2}$ (Larcher, 1995). So, leaf stomatal conductance as fundamental process in higher plants need to be stable to allow plant adaptation to environmental changes and low quality of soil and irrigation water (Souza et al., 2004)

The up-down fodder beet parts (top and root) are used in animal feeding, especially, roots (Ibrahim, 2005 and Turk, 2010), so, the optimum population which produces maximum leaves and roots yield must be taken in agronomist care. In this concern, Leilah et al. (2005) reported that the highest root yield of sugar beet grown in sandy soils was obtained with plant population of 114240 plants $\mathrm{ha}^{-1}$. However, Khogali et al. (2011) reported that hill spacing $(15,20,25 \mathrm{~cm})$ had no significant effects on fodder beet root and shoot fresh weights. Also, Al-Jbawi et al. (2016) could clarified the superiority of $25 \times 50$ plant density with the highest production traits as compared to other studied densities $(25 \times 50,30 \times 50,25 \times$ 60 and $30 \times 60 \mathrm{~cm}$.

As there is a limited information about fodder beet photosynthesis in relation to stomatal conductance and transpiration rate under different planting methods and planting densities at sandy soil conditions, this study was initiated to investigate fodder beet responses to transplanting and direct seeds under different planting densities.

\section{MATERIALS AND METHODS}

This experiment was conducted at the Experimental Farm, Faculty of Environmental Agricultural Science, Arish University, North Sinai Governorate, Egypt, during two winter seasons (2012/2013 and 2013/214). This work aimed to investigate the responses of fodder beet (Beta vulgaris L.) yield and some photosynthesis parameters to two planting methods (transplanting, T; Direct seeds, DS) under six planting densities (33.6, 28.0, 24.0, 21.0, 18.6, 16.8 thousand plants fad. ${ }^{-1}$ ). The used planting densities were resulted from six distances between irrigation lines i.e. 50, 60, 70, 80, 90, $100 \mathrm{~cm}$, with $25 \mathrm{~cm}$ within lines with $6.0 \mathrm{~m}$ long. Each experimental unit contained five lines which occupying area of $15,18,24,27$ and $30 \mathrm{~m}^{2}$ according to line widths $(50,60,70,80,90$ and $100 \mathrm{~cm}$, respectively). Each experiment included 12 treatments. A randomized complete block design in a split plot design (RCBD) in factorial experiment with three replications was used. Planting methods were randomly devoted in the main plots, while, planting densities were arranged in the sub-plots. The cultivated fooder beet cultivar was imported from Hungary called Beta Voroshenger by Forage Crops Research Section, ARC, Giza. Drip irrigation system was used with saline ground water (3500-4600 ppm) pumped from a local well. The total amount of water consumed during the growth season was estimated and was about $2600 \mathrm{~m}^{3}$ fad. $^{-1}$ as an average of the two studied seasons. The mechanical and chemical analyses of the soil at the experimental site are presented in Table 1.

The recommended rates of organic and chemical fertilizer were applied in each season. Organic manure $\left(15 \mathrm{~m}^{3} \mathrm{fad}^{-1}\right)$ and calcium super phosphate $\left(15 \% \mathrm{P}_{2} \mathrm{O}_{5}\right)$ at a rate of $100 \mathrm{~kg} \mathrm{fad}^{-1}$ were added during land preparation in the nursery then $200 \mathrm{~kg} \mathrm{fad}^{-1}$ were added in the permanent experimental field. Potassium sulphate $\left(48 \% \mathrm{~K}_{2} \mathrm{O}\right)$ at a rate of $100 \mathrm{~kg}$ fad. $^{-1}$ were applied at two equal doses; the first was added after 30 days and the second dose was after 90 days from sowing. Nitrogen fertilizer 
(Urea $46 \% \mathrm{~N}$ ) was added by the rate of $30 \mathrm{~kg} \mathrm{~N}$ fad. $^{-1}$ in the nursery after 21 days from sowing and by the rate of $60 \mathrm{~kg} \mathrm{~N}$ fad., ${ }^{-1}$ in the permanent experimental field at six equal doses through irrigation lines. The same rates and system of adding were used for direct seeds method $\left(15 \mathrm{~m}^{3}\right.$ fad. $^{-1}$ organic matter, $300 \mathrm{~kg}$ $\mathrm{P}_{2} \mathrm{O}_{5}$ fad. $^{-1}, 100 \mathrm{~kg} \mathrm{~K}_{2} \mathrm{O}$ fad. ${ }^{-1}$ and $90 \mathrm{~kg} \mathrm{~N}$ fad. $^{-1}$ ). All other agricultural practices were carried out as recommended.

Planting dates were on 29 Oct. in both seasons for direct seeds and nursery (seedling were transplanted after 45 days from sowing to the permanent experimental field). Harvesting took place on 9 June in both seasons. The following parameters were measured for both seasons:

Stomatal conductance and transpiration rates were measured on the newest fully expanding leaf and oldest green leaf on the plant after 75 days from sowing. Measurements were taken on five randomized plants of each treatment in all replications by steady state porometer (mode LI6400, Li-or, Lincoln, NE, USA) between 10.00 $\mathrm{AM}$ and $1.00 \mathrm{PM}$ at fully sun light (quantum) ranged between 1600-1800 $\mu \mathrm{mol} \mathrm{m}^{-2}$ sec. $^{-1}$, RH (45-49\%).

\section{Yield}

Five square meters area were harvested in each plot (Albayrak and Camae, 2006) to determine top and root fresh yields in $\mathrm{kg}$ then converted to ton $\mathrm{fad}^{-1}$. Ten guarded and randomized plants were taken to determine root length and diameter $(\mathrm{cm})$.

\section{Chemical Analyses}

Root crude protein (CP\%), crude fiber (CF\%), ash (\%) were determined according to the method mentioned in AOAC (1990). Ether extract (EE\%) was determined to calculate nitrogen free extract (NFE\%) as follows: NFE $(\%)=100-(\mathrm{CP}+\mathrm{CF}+\mathrm{Ash}+\mathrm{EE} \%)$. Total carbohydrates percentage (TCP\%) was determined according to standard laboratory procedures of forage quality analysis outlined by Ankom Technology (2008) by the formula of TCP (\%) = CF (\%) + NFE (\%). Macro and micro nutrients were determined according to AOAC (1990)

Data were analyzed using the standard analysis of variance (ANOVA) technique according to Steel and Torrie (2000). Mean values were separated using Duncan's multiple range test (Duncan, 1990).

Table 1. Average of soil mechanical and chemical analyses for the experimental site over the two seasons

\section{(1) Mechanical analysis: (Particle size distribution \%)}

Sand $(\%)$

Silt (\%)

Clay (\%)

Texture

(2) Chemical properties in (1:5) soil water extract:

Organic matter (\%)

$\mathrm{Ca} \mathrm{CO}_{3}(\%)$

$\mathrm{pH}$

EC (m mhos/cm 1:5)

Soluble ions ( $\mathrm{mg} \mathrm{l}^{-1}$ )

Cations

$\mathrm{Ca}^{++}$

$\mathrm{Mg}^{++}$

$\mathrm{K}^{+}$

0.32

$\mathrm{Na}^{+}$
70

25

5

Sandy loam

0.65

6.13

7.63

6.57

Anions

$\begin{array}{lc}\mathrm{H} \mathrm{CO}_{3}^{-1} & 6.3 \\ \mathrm{CL}^{-} & 15.02 \\ \mathrm{SO}_{4}^{--} & 1.84 \\ & \end{array}$




\section{RESULTS AND DISCUSSION}

The results and discussion were focused on the interaction effect between planting methods and densities on fodder beet photosynthetic activity and productivity.

\section{Photosynthetic Activity}

It is clear from the data in Tables $2 \mathrm{a}$ and $\mathrm{b}$ that treatments differed significantly with regard to stomatal conductance (Sc) and transpiration rate $(\mathrm{Tr})$ for the new and old leaves of both seasons and combined analysis. As for the main factor (plant method), results in Tables $2 \mathrm{a}$, b show that direct seeds method gave the higher values of Sc $\left(0.25 \mathrm{~cm} \mathrm{~s}^{-1}\right)$ and $\operatorname{Tr}\left(11.18 \mu \mathrm{g} \mathrm{cm}^{-2}\right.$ $\mathrm{s}^{-1}$ ) of the newest expanding leaf and $\operatorname{Tr}$ for the oldest ones $\left(2.86 \mu \mathrm{g} \mathrm{cm}^{-2} \mathrm{~s}^{-1}\right)$ in combined analysis. Concerning to the sub-main factor (plant density), planting fodder beet plants either with 21000 or 28000 plants fad. ${ }^{-1}$ gave the highest photosynthetic activity of the new leaf ( $\mathrm{Sc}_{c}=$ $0.30 \mathrm{~cm} \mathrm{~s}^{-1}, \operatorname{Tr}=14.75 \mu \mathrm{g} \mathrm{cm}^{-2} \mathrm{~s}^{-1}$ ) and old ones $\left(\mathrm{Sc}=0.09 \mathrm{~cm} \mathrm{~s}^{-1}\right)$, while, the highest $\operatorname{Tr}$ value of old leaf $\left(3.91 \mu \mathrm{g} \mathrm{cm}^{-2} \mathrm{~s}^{-1}\right)$ was obtained when plant density was 28000 plats fad. ${ }^{-1}$. However, the lowest values of Sc $\left(0.19 \mathrm{~cm} \mathrm{~s}^{-1}\right)$ and $\mathrm{Tr}$ $\left(8.48 \mu \mathrm{g} \mathrm{cm}^{-2} \mathrm{~s}^{-1}\right)$ were obtained from planting density of 16800 plants fad. ${ }^{-1}$, while, 33000 plants fad. ${ }^{-1}$ gave the lowest values of the Sc and Tr for old leaf $\left(0.04 \mathrm{~cm} \mathrm{~s}^{-1}, 1.29 \mu \mathrm{g} \mathrm{cm}^{-2} \mathrm{~s}^{-1}\right)$.

In concern to interaction effect, Table 2a cleared that transplanting (T.) with 28000 plants fad. $^{-1}$ and direct seeds (Ds.) with 21000 plants fad. $^{-1}$ treatments gave the highest values of stomatal conductance (Sc) $\left(0.31\right.$ and $\left.0.31 \mathrm{~cm} \mathrm{~s}^{-1}\right)$, while, T. with 33600, 16800 plants fad. ${ }^{-1}$ and Ds. with 33600 and 16800 plants fad. ${ }^{-1}$ gave the lowest values $\left(0.17,018,0.19\right.$ and $018 \mathrm{~m} \mathrm{~s}^{-1}$, respectively). In concern to $\mathrm{Tr}$., the highest

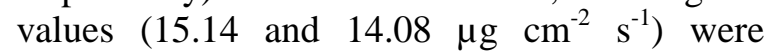
achieved by T. and Ds. with 28000 plant fad. ${ }^{-1}$ but the lowest ones (8.34 and $8.61 \mu \mathrm{g} \mathrm{cm}^{-2} \mathrm{~s}^{-1}$ ) were obtained from $\mathrm{T}$. and Ds. with 16800 plants fad. ${ }^{-1}$. Sc and Tr for the new fully expanding leaves were higher four times than old leaves (Table 2a, b). Data obtained from the oldest leaves indicated that the lowest values of Sc and $\operatorname{Tr}\left(0.03 \mathrm{~cm} \mathrm{~s}^{-1}, 1.13 \mu \mathrm{g} \mathrm{cm}^{-2} \mathrm{~s}^{-1}\right)$ were obtained from transplanting with 33600 plants fad. $^{-1}$ treatment (Table 2b). The reduction of photosynthesis rate as reflected of $\mathrm{S}$ and $\mathrm{Tr}$ were higher for upper canopy leaves 3-6 times than lower canopy leaves (Pearson et al., 1984) because increasing leaf age and shading declined both Sc and Tr faster than the younger leaf, so stomatal conductance and transpiration rate efficiency may be decreasing with aging. These results are in harmony with those obtained by El-Sarag (2013). The treatment of transplanting with 16800 plants/fad., gave the lowest Sc and $\operatorname{Tr}$ which may probably be due to covered the soil surface and causing drought of the soil. However, transplanting with 21000, 28000 plants fad. ${ }^{-1}$ treatments and direct seeds with 28000 plants fad. $^{-1}$ treatment gave the highest values of $\mathrm{Sc}$ and $\mathrm{Tr}$ than the other treatments as these dense plants covered soil surface well and reduced water evaporation from soil surface during their growth and development stages. Soil moisture is related to photosynthetic activities which reflected to higher yield and yield components. Also, photosynthesis measurements suggested that the new leaves maintain high photosynthetic rate capacity over long period and continue contributing more photosynthate to storage roots, whereas the old leaves decline with aging and consequently stomatal conductance (Sc) and transpiration rate ( $\mathrm{Tr}$ ) were sharply declined and productivity reduced. The new leaves assimilated about four times of photosynthate as much as in the oldest leaves. Therefore, it could be more beneficial to cut the old leaves for animal feeding during the period of fodder beet growth to develop and regenerate more new leaves with high efficiency of photosynthetic rate, stomatal conductance and transpiration rate as well.

\section{Root Dimension and Yield}

Results in Table 3 indicated that root length and diameter responded significantly to different planting methods and densities in both seasons and combined analysis. Direct seeds treatment resulted higher root length and diameter (29.33, $43.36 \mathrm{~cm}$ ) than transplanting ones (29.09, 42.11 $\mathrm{cm}$ ) in combined analysis. Planting fodder beet plants by 21000 plants fad. ${ }^{-1}$ gave the highest root length $(33.39 \mathrm{~cm})$ followed by 24000 , 28000 and 33600 plants fad. ${ }^{-1}$ (31.01, 30.76, $30.01 \mathrm{~cm}$, respectively) but the highest root diameter $(48.82 \mathrm{~cm})$ was obtained from 28000 
Table 2a. Means of stomatal conductance $\left(\mathrm{cm} \mathrm{s}^{-1}\right)$ and transpiration rate $\left(\mu \mathrm{gm}^{-2} \mathrm{~s}^{-1}\right)$ of the newest fully expanding leaf of fodder beet under planting methods, densities and their interaction for two growing seasons and combined analysis

\begin{tabular}{|c|c|c|c|c|c|c|c|}
\hline \multirow[t]{2}{*}{ Parameters } & & \multicolumn{3}{|c|}{ Stomatal conductance $\left(\mathrm{cm} \mathrm{s}^{-1}\right)$} & \multicolumn{3}{|c|}{ Transpiration rate $\left(\mu \mathrm{g} \mathrm{cm}^{-2} \mathrm{~s}^{-1}\right)$} \\
\hline & & $12 / 2013$ & $13 / 2014$ & $\begin{array}{c}\text { Combined } \\
\text { analysis }\end{array}$ & $12 / 2013$ & $13 / 2014$ & $\begin{array}{c}\text { Combined } \\
\text { analysis }\end{array}$ \\
\hline \multirow{4}{*}{$\begin{array}{l}\text { Planting } \\
\text { method }\end{array}$} & Transplanting & $0.23 \mathrm{~b}$ & $0.24 \mathrm{~b}$ & $0.23 \mathrm{~b}$ & $10.59 \mathrm{~b}$ & 11.50 & $11.04 \mathrm{~b}$ \\
\hline & Direct seeds & $0.24 \mathrm{a}$ & $0.26 \mathrm{a}$ & $0.25 \mathrm{a}$ & $11.10 \mathrm{a}$ & 11.30 & $11.18 \mathrm{a}$ \\
\hline & 33.6 & $0.18 \mathrm{~cd}$ & $0.19 \mathrm{c}$ & $0.19 \mathrm{c}$ & $8.89 \mathrm{c}$ & $10.09 \mathrm{bcd}$ & $9.54 \mathrm{~cd}$ \\
\hline & 28.0 & $0.30 \mathrm{a}$ & $0.29 \mathrm{ab}$ & $0.29 \mathrm{ab}$ & 15.63 a & $14.08 \mathrm{a}$ & $14.75 \mathrm{a}$ \\
\hline \multirow{4}{*}{$\begin{array}{l}\text { Plant density } \\
\text { (Thousand } \\
\text { plants fad. }^{-1} \text { ) }\end{array}$} & 24.0 & $0.23 \mathrm{~cd}$ & $0.24 \mathrm{bc}$ & $0.24 \mathrm{c}$ & $11.34 \mathrm{~b}$ & 11.17 bc & 10.87 bc \\
\hline & 21.0 & $0.28 \mathrm{ab}$ & $0.31 \mathrm{a}$ & $0.30 \mathrm{a}$ & $11.88 \mathrm{~b}$ & $12.04 \mathrm{~b}$ & $11.92 \mathrm{~b}$ \\
\hline & 18.6 & $0.26 \mathrm{bcd}$ & $0.28 \mathrm{ab}$ & $0.27 \mathrm{bc}$ & $10.98 \mathrm{bc}$ & 11.92 bc & 11.25 bc \\
\hline & 16.8 & $0.18 \mathrm{~d}$ & $0.19 \mathrm{c}$ & $0.19 \mathrm{~d}$ & $8.13 \mathrm{c}$ & $9.02 \mathrm{~cd}$ & $8.48 \mathrm{~d}$ \\
\hline \multicolumn{8}{|c|}{ Interaction between Planting method and Plant density } \\
\hline \multirow{6}{*}{ Transplanting } & 33.6 & $0.18 \mathrm{~cd}$ & $0.19 \mathrm{c}$ & $0.18 c$ & 9.11def & $9.22 \mathrm{~cd}$ & 9.16de \\
\hline & 28.0 & $0.34 \mathrm{a}$ & $0.28 \mathrm{a}$ & $0.31 \mathrm{a}$ & $14.10 \mathrm{ab}$ & $16.25 a$ & $15.41 \mathrm{a}$ \\
\hline & 24.0 & 0.19cd & $0.21 \mathrm{bc}$ & $0.20 \mathrm{bc}$ & 10.30cdef & $10.85 b c d$ & $10.58 \mathrm{bcd}$ \\
\hline & 21.0 & $0.30 \mathrm{ab}$ & $0.29 \mathrm{ab}$ & $0.29 \mathrm{a}$ & $11.35 \mathrm{~cd}$ & $12.25 b$ & $11.80 \mathrm{bc}$ \\
\hline & 18.6 & $0.23 \mathrm{bcd}$ & $0.26 \mathrm{abcd}$ & $0.25 \mathrm{ab}$ & 10.58cde & $11.88 \mathrm{bc}$ & $11.21 \mathrm{bc}$ \\
\hline & 16.8 & $0.16 \mathrm{~d}$ & $0.18 c$ & $0.17 \mathrm{c}$ & $8.11 \mathrm{ef}$ & $8.55 d$ & 8.34e \\
\hline \multirow{6}{*}{ Direct seed } & 33.6 & $0.17 d$ & $0.20 \mathrm{~cd}$ & $0.18 c$ & 8.88def & 10.95bcd & 9.91cde \\
\hline & 28.0 & $0.26 \mathrm{abc}$ & $0.30 \mathrm{a}$ & $0.28 \mathrm{a}$ & $16.25 a$ & $11.90 \mathrm{bc}$ & $14.08 \mathrm{a}$ \\
\hline & 24.0 & $0.26 \mathrm{abc}$ & $0.26 \mathrm{abcd}$ & $0.26 \mathrm{ab}$ & 10.83cde & $11.48 b c$ & 11.15bc \\
\hline & 21.0 & $0.26 \mathrm{abc}$ & $0.33 a$ & $0.30 \mathrm{a}$ & $12.28 \mathrm{bc}$ & $11.83 \mathrm{bc}$ & $12.05 b$ \\
\hline & 18.6 & $0.28 \mathrm{ab}$ & $0.29 \mathrm{ab}$ & $0.26 \mathrm{ab}$ & 10.63cde & $11.95 b c$ & $11.29 b c$ \\
\hline & 16.8 & 0.19cd & $0.20 \mathrm{~cd}$ & $0.19 c$ & $7.73 \mathrm{f}$ & 9.48bcd & 8.61e \\
\hline
\end{tabular}


Table 2b. Means of stomatal conductance $\left(\mathrm{cm} \mathrm{s}^{-1}\right)$ and transpiration rate $\left(\mu \mathrm{gm}^{-2} \mathrm{~s}^{-1}\right)$ of the oldest leaf of fodder beet under planting methods, densities and their interaction for two growing seasons and combined analysis

\begin{tabular}{|c|c|c|c|c|c|c|c|}
\hline \multirow[t]{2}{*}{$\overline{\text { Parameters }}$} & & \multicolumn{3}{|c|}{ Stomatal conductance $\left(\mathrm{cm} \mathrm{s}^{-1}\right)$} & \multicolumn{3}{|c|}{ Transpiration rate $\left(\mu \mathrm{g} \mathrm{cm}^{-2} \mathrm{~s}^{-1}\right)$} \\
\hline & & $12 / 2013$ & $13 / 2014$ & $\begin{array}{c}\text { Combined } \\
\text { analysis }\end{array}$ & $12 / 2013$ & $13 / 2014$ & $\begin{array}{c}\text { Combined } \\
\text { analysis }\end{array}$ \\
\hline \multirow{4}{*}{$\begin{array}{l}\text { Planting } \\
\text { method }\end{array}$} & Transplanting & 0.06 & 0.07 & 0.06 & $2.53 \mathrm{~b}$ & $2.96 \mathrm{ab}$ & $2.64 \mathrm{ab}$ \\
\hline & Direct seeds & 0.06 & 0.07 & 0.07 & $2.80 \mathrm{a}$ & $2.74 \mathrm{~b}$ & $2.86 \mathrm{a}$ \\
\hline & 33.6 & $0.03 \mathrm{bc}$ & 0.08 & $0.04 \mathrm{~d}$ & $1.23 \mathrm{~cd}$ & $2.54 \mathrm{bcd}$ & $1.29 \mathrm{~d}$ \\
\hline & 28.0 & $0.09 \mathrm{a}$ & 0.07 & $0.09 \mathrm{a}$ & $4.10 \mathrm{a}$ & $3.70 \mathrm{a}$ & $3.91 \mathrm{a}$ \\
\hline \multirow{4}{*}{$\begin{array}{l}\text { Plant density } \\
\text { (Thousand } \\
\text { plants fad. }{ }^{-1} \text { ) }\end{array}$} & 24.0 & $0.06 \mathrm{abc}$ & 0.04 & $0.06 \mathrm{bcd}$ & $2.71 \mathrm{bcd}$ & $3.43 \mathrm{ab}$ & 2.77 bcd \\
\hline & 21.0 & $0.08 \mathrm{ab}$ & 0.05 & $0.09 \mathrm{a}$ & 3.38 bc & 3.17 bc & $3.52 \mathrm{ab}$ \\
\hline & 18.6 & $0.06 \mathrm{abc}$ & 0.08 & $0.06 \mathrm{bcd}$ & 2.71 bd & $2.56 \mathrm{bcd}$ & $2.82 \mathrm{bcd}$ \\
\hline & 16.8 & $0.04 \mathrm{abc}$ & 0.07 & $0.05 \mathrm{~cd}$ & $1.88 \mathrm{~cd}$ & $1.73 \mathrm{~cd}$ & $2.41 \mathrm{~cd}$ \\
\hline \multicolumn{8}{|c|}{ Interaction between planting method and plant density } \\
\hline \multirow{6}{*}{ Transplanting } & 33.6 & $0.02 \mathrm{bc}$ & 0.04 & $0.03 \mathrm{~d}$ & $1.10 \mathrm{~h}$ & $1.15 \mathrm{f}$ & $1.13 \mathrm{~g}$ \\
\hline & 28.0 & $0.08 \mathrm{ab}$ & 0.09 & $0.09 \mathrm{a}$ & $4.15 \mathrm{a}$ & $4.50 \mathrm{a}$ & $4.33 \mathrm{a}$ \\
\hline & 24.0 & $0.05 \mathrm{abc}$ & 0.06 & $0.05 \mathrm{bcd}$ & 2.55 cde & 3.98 a & $2.65 \mathrm{~d}$ \\
\hline & 21.0 & $0.08 \mathrm{ab}$ & 0.09 & $0.09 \mathrm{a}$ & 3.13 bc & $3.33 \mathrm{~b}$ & $3.23 \mathrm{c}$ \\
\hline & 18.6 & $0.06 \mathrm{abc}$ & 0.07 & 0.06 abcd & 2.48 de & $2.88 \mathrm{~b}$ & $2.68 \mathrm{~d}$ \\
\hline & 16.8 & $0.04 \mathrm{abc}$ & 0.04 & $0.04 \mathrm{~cd}$ & $1.78 \mathrm{f}$ & 1.90 de & $1.84 \mathrm{ef}$ \\
\hline \multirow{6}{*}{ Direct seed } & 33.6 & $0.03 \mathrm{bc}$ & 0.05 & $0.04 \mathrm{~cd}$ & 1.35gh & 3.93a & $1.45 \mathrm{fg}$ \\
\hline & 28.0 & $0.09 a$ & 0.09 & $0.09 a$ & $4.05 a$ & $2.90 \mathrm{~b}$ & 3.99ab \\
\hline & 24.0 & 0.07abc & 0.07 & 0.07abc & $2.85 \mathrm{~cd}$ & $11.48 \mathrm{bc}$ & $2.88 \mathrm{~cd}$ \\
\hline & 21.0 & 0.08ab & 0.08 & 0.08ab & 3.63ab & $3.00 \mathrm{~b}$ & $3.80 \mathrm{~b}$ \\
\hline & 18.6 & 0.06abc & 0.07 & 0.06a-d & 2.93cd & $2.20 \mathrm{~cd}$ & 2.96cd \\
\hline & 16.8 & 0.04abc & 0.05 & $0.05 b c d$ & $1.98 \mathrm{ef}$ & $1.55 \mathrm{ef}$ & $2.09 \mathrm{e}$ \\
\hline
\end{tabular}


Table 3. Means of root length $(\mathrm{cm})$ and root diameter $(\mathrm{cm})$ of fodder beet under planting methods, densities and their interaction for two growing seasons and combined analysis

\begin{tabular}{|c|c|c|c|c|c|c|c|}
\hline \multirow[t]{2}{*}{ Parameters } & & \multicolumn{3}{|c|}{ Root length (cm) } & \multicolumn{3}{|c|}{ Root diameter $(\mathrm{cm})$} \\
\hline & & $12 / 2013$ & $13 / 2014$ & $\begin{array}{c}\text { Combinec } \\
\text { analysis }\end{array}$ & $12 / 2013$ & $13 / 2014$ & $\begin{array}{c}\text { Combined } \\
\text { analysis }\end{array}$ \\
\hline \multirow{4}{*}{$\begin{array}{l}\text { Planting } \\
\text { method }\end{array}$} & Transplanting & $25.27 a b$ & $32.90 \mathrm{a} \mathrm{b}$ & $29.09 \mathrm{~b}$ & $41.30 \mathrm{~b}$ & $41.30 \mathrm{~b}$ & $42.11 \mathrm{~b}$ \\
\hline & Direct seeds & $24.41 \mathrm{~b}$ & 34.25 a & 29.33 a & $45.48 \mathrm{a}$ & $41.54 \mathrm{ab}$ & $43.36 \mathrm{a}$ \\
\hline & 33.6 & 22.99 & $36.86 \mathrm{ab}$ & $30.01 \mathrm{abc}$ & $49.52 \mathrm{ab}$ & $44.59 \mathrm{ab}$ & $46.63 \mathrm{ab}$ \\
\hline & 28.0 & 26.78 & $34.34 \mathrm{ab}$ & $30.76 \mathrm{abc}$ & 51.09 a & $46.54 \mathrm{a}$ & $48.82 \mathrm{a}$ \\
\hline \multirow{4}{*}{$\begin{array}{c}\text { Plant density } \\
\text { (Thousand } \\
\text { plants fad.- }{ }^{-1} \text { ) }\end{array}$} & 24.0 & 26.05 & $35.98 a b$ & $31.01 \mathrm{ab}$ & $46.81 \mathrm{abc}$ & $44.94 \mathrm{ab}$ & 45.87 abcd \\
\hline & 21.0 & 28.17 & 38.13 a & 33.39 a & 44.51 bc & $39.66 \mathrm{bcd}$ & $42.08 \mathrm{bcd}$ \\
\hline & 18.6 & 23.45 & 30.99 abc & 27.28 bc & $40.33 \mathrm{bcd}$ & $38.96 \mathrm{~cd}$ & 39.63 cde \\
\hline & 16.8 & 21.85 & 25.14 bc & $23.24 \mathrm{c}$ & $33.11 \mathrm{~d}$ & $33.83 \mathrm{~d}$ & $33.41 \mathrm{e}$ \\
\hline \multicolumn{8}{|c|}{ Interaction between planting method and plant density } \\
\hline \multirow{6}{*}{ Transplanting } & 33.6 & 24.90 & $35.23 a b$ & $30.06 a b$ & 44.93abc & 41.40ab & 43.16 bcd \\
\hline & 28.0 & 28.85 & 35.98ab & 32.46ab & $52.58 \mathrm{a}$ & $47.00 \mathrm{a}$ & $49.79 \mathrm{ab}$ \\
\hline & 24.0 & 26.00 & 32.23abc & 29.11ab & 47.00ab & $47.60 \mathrm{a}$ & $47.30 \mathrm{abc}$ \\
\hline & 21.0 & 27.18 & $37.60 \mathrm{a}$ & 32.39ab & 44.43abc & $40.08 a b$ & 42.25 cde \\
\hline & 18.6 & 22.43 & 30.38abc & $26.40 \mathrm{bc}$ & $39.60 \mathrm{bc}$ & 38.38ab & 38.99 de \\
\hline & 16.8 & 22.25 & $25.95 b c$ & $24.10 \mathrm{c}$ & $29.00 \mathrm{~d}$ & 33.33b & $31.16 \mathrm{e}$ \\
\hline \multirow{6}{*}{ Direct seed } & 33.6 & 21.43 & $38.48 a$ & 29.95abc & $54.10 \mathrm{a}$ & $47.78 a$ & $50.04 \mathrm{a}$ \\
\hline & 28.0 & 25.43 & 32.70abc & 29.06abc & 49.60ab & 46.08a & $47.84 \mathrm{ab}$ \\
\hline & 24.0 & 26.10 & 39.73a & 32.91ab & 46.60abc & 42.28ab & 44.44abcd \\
\hline & 21.0 & 30.75 & $38.65 a$ & 34.39a & 44.58ab & 39.23ab & 41.90cde \\
\hline & 18.6 & $24.70 a$ & 31.60abc & 28.15abc & $41.00 \mathrm{bc}$ & 39.53ab & 40.26de \\
\hline & 16.8 & 20.43 & $24.33 c$ & $22.38 c$ & $37.00 \mathrm{cdc}$ & $34.33 \mathrm{~b}$ & 35.66ef \\
\hline
\end{tabular}

Means have the same letters in the same column are not significantly different at $\mathrm{P} \leq 0.05$ level. 
plants fad. ${ }^{-1}$ in combined analysis. However, the lowest plant density (16800 plants fad. ${ }^{-1}$ ) gave the lowest root length and diameter (23.24, $33.41 \mathrm{~cm}$ ) in combined analysis. Concerning to the interaction effect, direct seeds treatment with 21000 and 33600 plants fad. $^{-1}$ gave the highest root length $(34.39 \mathrm{~cm})$ and root diameter $(50.04$ $\mathrm{cm})$, while, the lowest values $(22.38,31.16 \mathrm{~cm})$ were obtained from both Ds. with 16800 and T. with 18600 plants $\mathrm{fad}^{-1}$. Similar results were found by Pospisil et al. (2000), where they explained that increasing the plant density from 40,000 to 160,000 plants per hectare resulted in leaf surface reduction in each plant, so, the growth and root yield of sugar beet plants is almost consistent.

Total yield (Top and root) had significant difference according to different planting methods and densities in both seasons and combined analysis (Table 4). In combined analysis, Ds treatment gave higher top, root and total fresh yields (11.3, 106.2, $117.5 \mathrm{t} \mathrm{fad}^{-1}$, respectively) as compared to $\mathrm{T}$. treatment. Superiorities of 28000, 24000 and 21000 plants fad. ${ }^{-1}$ were recorded for top fresh yield (12.7, 12.6, $12.9 \mathrm{t} \mathrm{fad}^{-1}$, respectively), while, the highest root and total fresh yields $(126.5,139.2 \mathrm{t}$ fad. $^{-1}$ ) were achieved from 28000 plants fad. ${ }^{-1}$ treatment followed by 24000 plants fad. $^{-1}$ without significant difference (123.4, $135.0 \mathrm{t}$ fad. $\left.{ }^{-1}\right)$. However, the lowest top, root and total fresh yields (7.6, 62.9, $70.5 \mathrm{t} \mathrm{fad}^{-1}$ ) were gained from 16800 plants fad. $^{-1}$

In respect to interaction effect, in the first season, data showed that the maximum total fresh yield (149.6 ton fad. ${ }^{-1}$ ) was achieved when fodder beet was cultivated by direct seeds with 21000 plants $\mathrm{fad}^{-1}$., followed by 28000 plants $\mathrm{fad}^{-1}$., with mean value 141.0 ton $\mathrm{fad}^{-1}$. However, the minimum total yield (57.9 ton fad. ${ }^{-1}$ ) was obtained with transplanting fodder beet with 16800 plants fad. ${ }^{-1}$. Concerning to the second season, direct seeds with 21000 plants fad ${ }^{-1}$., gave the highest mean of total fresh yield (152.1 ton fad. $^{-1}$ ), while, transplanting with 16800 plants fad $^{-1}$., gave the lowest mean (63.3 ton fad. ${ }^{-1}$ ). In combined analysis over the two growing seasons, the same trend was realized with highest mean value of total fresh yield (150.9 ton fad. ${ }^{-1}$ ) which obtained from direct seed method with 21000 plants fad. ${ }^{-1}$, while, the lowest mean value (60.6 ton fad. ${ }^{-1}$ ) was gained from transplanting method with 16800 plants $\mathrm{fad}^{-1}$. Similar results were provided by El-Sarag et al. (2005)

\section{Simple Correlation Coefficient}

The relationship among the studied criteria are shown in Table 5 which show simple correlation coefficient between total fresh yield (Top, Root) and some parameters. Top, root and total fresh yield were highly and significantly $(P \leq 0.01)$ correlated with root length $(r=0.880$, $0.821,0.829$, respectively), while, root diameter was significantly correlated with root and total fresh yields $(r=0.702,0.699)$. However, there were no significant correlation for root diameter and top yield. New leaf transpiration rate (Tr) was significantly correlated with top, root and total fresh yields $(r=0.603,0.612,0.596$, respectively). Finally, high total fresh yield tended to have high positive correlation with root length and diameter as well as transpiration rate of new leaf. This means that the increase in root length, root diameter and new leaf transpired would be associated with the increase in total fresh yield of fodder beet. So, these parameters could be an important factors for improving total yield of fodder beet under sandy soil conditions (Albayrak and Yuksel, 2009, 2010).

\section{Chemical Composition}

Comparing to various chemical constituents among the twelve treatments and over the two growing seasons, data in Table 6 show chemical composition and feeding value of fodder beet roots grown in sandy soil of North Sinai Governorate. Composition of macronutrients such as $\mathrm{P}, \mathrm{K}, \mathrm{Ca}$ and $\mathrm{Mg}$ was more balanced for feeding on fodder beet. Therefore, the treatments which gave the highest range of these elements may be very useful for improving the feeding value and quality of fodder beet. Improvement in $\mathrm{P}$ content is necessary to obtain low $\mathrm{Ca} / \mathrm{P}$ and $\mathrm{K} / \mathrm{Ca}$ ratios which are a desirable characteristics in forage for animal feeding. Similar results were obtained on sugar beet by Leilah et al. (2005) and Jafarnia et al. (2013), where they reported that increasing plant density caused reduction in root potassium and sodium content. Concerning the micronutrient continents of $\mathrm{Fe}, \mathrm{Mn}, \mathrm{Zn}$ and $\mathrm{Cu}$, they were differed significantly between and 
Table 4. Means of top, root and total fresh yields (ton fad..$^{-1}$ ) of fodder beet under planting methods, densities and their interaction for two growing seasons and combined analysis

\begin{tabular}{|c|c|c|c|c|c|c|c|c|c|c|}
\hline \multirow[t]{3}{*}{ Season } & & \multicolumn{3}{|c|}{$2012 / 2013$} & \multicolumn{3}{|c|}{$2013 / 2014$} & \multicolumn{3}{|c|}{ Combined analysis } \\
\hline & & \multicolumn{9}{|c|}{ Fresh yield (ton fad..$^{-1}$ ) } \\
\hline & & Top & Root & Total & Top & Root & Total & Top & Root & Total \\
\hline \multirow{4}{*}{$\begin{array}{l}\text { Planting } \\
\text { method }\end{array}$} & Transplanting & $10.6 \mathrm{~b}$ & $92.6 \mathrm{~b}$ & $103.2 \mathrm{~b}$ & 11.7 & $96.1 \mathrm{~b}$ & $107.4 \mathrm{~b}$ & $10.8 \mathrm{~b}$ & $94.5 \mathrm{~b}$ & $105.3 \mathrm{~b}$ \\
\hline & Direct seeds & $11.1 \mathrm{a}$ & $104.6 \mathrm{a}$ & $115.6 \mathrm{a}$ & 11.5 & $107.9 \mathrm{a}$ & $119.4 \mathrm{a}$ & $11.3 \mathrm{a}$ & $106.2 \mathrm{a}$ & $117.5 \mathrm{a}$ \\
\hline & 33.6 & $10.9 \mathrm{abc}$ & $=97.9 \mathrm{c}$ & $108.8 \mathrm{~cd}$ & $11.2 \mathrm{bcd}$ & $101.4 \mathrm{C}$ & $112.8 \mathrm{~b}$ & $11.1 \mathrm{bcd}$ & 99.7 bcd & $110.8 \mathrm{~cd}$ \\
\hline & 28.0 & $12.7 \mathrm{a}$ & $124.1 \mathrm{a}$ & $118.4 \mathrm{bcc}$ & $12.8 \mathrm{abc}$ & $128.9 \mathrm{a}$ & $141.7 \mathrm{a}$ & $12.7 \mathrm{ab}$ & $126.5 \mathrm{a}$ & 139.2 a \\
\hline \multirow{4}{*}{$\begin{array}{c}\text { Plant density } \\
\text { (Thousand } \\
\text { plants fad. }^{-1} \text { ) }\end{array}$} & 24.0 & $12.7 \mathrm{a}$ & 120.8 abc & $133.5 \mathrm{a}$ & $12.5 \mathrm{abc}$ & $125.9 \mathrm{ab}$ & $138.4 \mathrm{ab}$ & $12.6 \mathrm{ab}$ & 123.4 abc & $135.9 \mathrm{ab}$ \\
\hline & 21.0 & $12.4 \mathrm{ab}$ & $112.2 \mathrm{bc}$ & $124.8 \mathrm{~b}$ & $13.3 \mathrm{abc}$ & $115.3 \mathrm{~b}$ & $128.7 \mathrm{ab}$ & $12.9 \mathrm{ab}$ & $113.9 \mathrm{bcd}$ & $126.8 \mathrm{bcd}$ \\
\hline & 18.6 & $9.0 \mathrm{bc}$ & $75.8 \mathrm{~d}$ & $84.8 \mathrm{~d}$ & $10.3 \mathrm{~cd}$ & $75.9 \mathrm{~d}$ & $85.6 \mathrm{c}$ & $9.7 \mathrm{c}$ & $75.9 \mathrm{c}$ & $85.4 \mathrm{c}$ \\
\hline & 16.8 & $7.5 \mathrm{c}$ & 60.7 e & $68.1 \mathrm{e}$ & $7.7 \mathrm{~d}$ & $65.2 \mathrm{e}$ & $72.9 \mathrm{~d}$ & $7.6 \mathrm{~d}$ & $62.9 \mathrm{~d}$ & $70.5 \mathrm{~d}$ \\
\hline \multicolumn{11}{|c|}{ Interaction between planting method and plant density } \\
\hline \multirow{6}{*}{ Transplanting } & 33.6 & $11.4 \mathrm{c}$ & $110.4 \mathrm{f}$ & $121.8 \mathrm{f}$ & 11.9d & 113.5e & $125.7 e$ & 11.7de & $112.1 \mathrm{f}$ & $123.8 \mathrm{e}$ \\
\hline & 28.0 & $13.9 \mathrm{a}$ & $127.1 \mathrm{~b}$ & $141.0 \mathrm{~b}$ & $14.0 \mathrm{~b}$ & $135.1 b$ & $149.1 b$ & $13.9 \mathrm{~b}$ & 131.1b & $145.0 \mathrm{~b}$ \\
\hline & 24.0 & $12.8 \mathrm{~b}$ & 116.9e & $129.7 \mathrm{e}$ & $13.0 \mathrm{c}$ & $122.2 d$ & $135.2 d$ & $12.9 \mathrm{c}$ & 119.5e & $132.5 d$ \\
\hline & 21.0 & $10.7 d$ & 89.3h & $100.0 \mathrm{~g}$ & 11.0def & $94.3 g$ & $105.3 f$ & 10.9ef & $91.8 \mathrm{~h}$ & $102.6 f$ \\
\hline & 18.6 & $8.9 \mathrm{e}$ & $59.8 \mathrm{k}$ & $68.8 \mathrm{j}$ & 9.8gh & 55.9j & $65.7 \mathrm{i}$ & $9.4 \mathrm{~h}$ & $57.9 \mathrm{k}$ & $67.2 \mathrm{i}$ \\
\hline & 16.8 & $5.8 f$ & $52.1 \mathrm{i}$ & $57.9 \mathrm{k}$ & $6.3 \mathrm{i}$ & 56.9j & $63.3 \mathrm{j}$ & $6.1 \mathrm{i}$ & $54.5 \mathrm{i}$ & $60.6 j$ \\
\hline \multirow{6}{*}{ Direct seed } & 33.6 & $10.4 d$ & $85.3 \mathrm{i}$ & $95.7 \mathrm{~h}$ & $10.4 \mathrm{fg}$ & 89.3h & $99.8 \mathrm{~g}$ & $10.4 \mathrm{fg}$ & 87.3i & $97.8 \mathrm{~g}$ \\
\hline & 28.0 & $11.4 \mathrm{c}$ & 120.9d & $132.3 d$ & 11.6de & $122.7 d$ & $134.2 d$ & 11.5de & $121.8 \mathrm{~d}$ & 133.3d \\
\hline & 24.0 & $12.5 \mathrm{~d}$ & $124.7 \mathrm{c}$ & $137.2 \mathrm{c}$ & 11.9d & $129.7 \mathrm{c}$ & $141.5 c$ & $12.2 \mathrm{~d}$ & $127.2 \mathrm{c}$ & $139.4 \mathrm{c}$ \\
\hline & 21.0 & $14.1 \mathrm{a}$ & 135.5a & $149.6 a$ & $15.6 \mathrm{a}$ & 136.5a & $152.1 \mathrm{a}$ & 14.8a & $136.0 \mathrm{a}$ & $150.9 a$ \\
\hline & 18.6 & $9.1 \mathrm{e}$ & $91.7 \mathrm{~g}$ & $100.8 \mathrm{~g}$ & 10.7efg & $95.8 \mathrm{f}$ & $105.5 f$ & 9.9gh & 93.8g & $103.5 f$ \\
\hline & 16.8 & 8.9e & 69.3j & $78.2 \mathrm{i}$ & 9.1h & $73.4 \mathrm{i}$ & $82.5 \mathrm{~h}$ & $9.0 \mathrm{~h}$ & $71.4 \mathrm{j}$ & $80.4 \mathrm{~h}$ \\
\hline
\end{tabular}

Means have the same letters in the same column are not significantly different at $\mathrm{P} \leq 0.05$ level. 
Table 5. Simple correlation coefficients between total fresh yield (top + root) and each of root length, root diameter, new leaf stomatal conductance (New leaf Sc), new leaf transpiration rate (New leaf $\mathrm{Tr}$ ), old stomatal conductance (Old leaf Sc) and old transpiration rate (Old leaf Tr) of fodder beet over the both studied seasons (2012/2013 and 2013/2014)

\begin{tabular}{lccc}
\hline Parameter & Top yield & Root yield & Total yield (Top + Root) \\
\hline Root length & $0.880^{* *}$ & $0.821^{* *}$ & $0.829^{* *}$ \\
Root diameter & $0.383 \mathrm{NS}$ & $0.702^{*}$ & $0.699^{*}$ \\
New leaf Sc & $0.499 \mathrm{NS}$ & $0.489 \mathrm{NS}$ & $0.489 \mathrm{NS}$ \\
New leaf Tr & $0.603^{*}$ & $0.612^{*}$ & $0.596^{*}$ \\
Old leaf Sc & $0.478 \mathrm{NS}$ & $0.479 \mathrm{NS}$ & $0.471 \mathrm{NS}$ \\
Old leaf Tr & $0.528 \mathrm{NS}$ & $0.531 \mathrm{NS}$ & $0.519 \mathrm{NS}$ \\
\hline
\end{tabular}

*,** and NS indicate significant at $0.05,0.01$ probability level and not significant

Table 6. Chemical composition of fodder beet roots over the studied treatment and growing seasons under sandy soil conditions of North Sinai Governorate

\begin{tabular}{lccc}
\hline Parameter & Range & Average & Coefficient of variation (\%) \\
\hline Crude protein (\%) & $13.6-11.0$ & 12.3 & 5.40 \\
Crude fiber (\%) & $6.1-5.1$ & 5.6 & 4.90 \\
Carbohydrate (\%) & $74.5-70.0$ & 72.3 & 7.80 \\
Ash (\%) & $13.0-6.5$ & 9.8 & 8.88 \\
P (\%) & $0.29-0.18$ & 0.24 & 8.49 \\
K (\%) & $6.00-2.19$ & 4.10 & 6.14 \\
Ca (\%) & $1.84-0.71$ & 1.28 & 6.50 \\
Mg (\%) & $0.95-63.0$ & 0.71 & 3.35 \\
Fe (ppm) & $415.8-302.5$ & 359.2 & 7.50 \\
Mn (ppm) & $95.8-63.0$ & 79.4 & 10.0 \\
Zn (ppm) & $65.3-30.0$ & 47.7 & 11.62 \\
Cu (ppm) & $19.9-10.6$ & 15.3 & 5.90 \\
\hline
\end{tabular}

*, ** and NS indicate significant at $0.05,0.01$ probability level and not significant 
within treatments. Iron content reached about 4.5, 7.5 and 23.5 times as much as, Mn, Zn and $\mathrm{Cu}$, respectively. However, transplanting method with lowest plant density improved fodder beet content by having higher micronutrients than the highest ones. In this respect, the deficiencies of trace elements caused serious disturbances in productivity and fertility of animals resulting in a low reproduction rate and early sterility. These results are probably due to the plants' reaction to the environmental condition such as shorter daylight hours and colder nighttime temperatures. These results are in harmony with those obtained by Albayrak and Camae (2006) and Tiryakioglu or and Turk (2012).

\section{Conclusion}

According to the mentioned results of this investigation, it could be recommended to cultivate fodder beet directly by seeds with 21000 plants fad. $^{-1}$ (80 cm between lines) to maximize its photosynthetic activity and total fresh yield under sandy soil conditions of North Sinai Governorate and similar areas.

\section{REFERENCES}

Albayrak, S. and N. Camae (2006). Yield components of fodder beet (Beta vulgaris var. crassa mansf.) under the Middle Black Sea region conditions. Tarem Bilimleri Dergisi, 12 (1): 65-69.

Albayrak, S. and O. Yuksel (2010). Effects of nitrogen fertilization and harvest time on root yield and quality of fodder beet (Beta vulgaris var. crassa mansf.). Turkish J. Field Crops, 15 (1): 59-64.

Albayrak, S. and O. Yuksel (2009). Leaf area prediction model for sugar beet and fodder beet. Suleiman Demirel Univeritesi, Feu Bilimleri Enstitusu Dergisi, $13(1)$ : 20-24.

Al-Jbawi, E., S. Al-Geddawi, G. Alesha and H. Al-Zubi (2016). Productivity of fodder beet (Beta vulgaris var. Crassa) cultivars as affected by plants spacing in Al Ghab, Syria. J. Agric. and Crop Res., 4 (6): 91-99.
Ankom Technology (2008). http:// www.a nkom.com/00_products/product_a2000. shtml; verified 10 September 2008)

AOAC (1990). Official Methods of Analysis. $5^{\text {th }}$ Ed. AOAC, Washington, 25, DC, USA.

Ashraf, M. and P.J. Harris (2004). Potential biochemical indicators of salinity tolerance in plants. Plant Sci., 166: 3-16.

Ashraf, M. and M.R. Foolad (2007). Role of glycine betanine and proline in improving plant abiotic stress resistance. Environ. Exp. Bot., 59 : 206-216.

Brugnoli, E. and M. Lauteri (1991). Effect of salinity on stomatal conductance, photosynthetic capacity and carbon isotope discrimination of salt resistant (Gossipum hirstum L.) and salt sensitive (Phaseolus vulgaris L.) 3 non-halophytes. Plant Physiol., 95: 628-635.

Cha-um, S. and C. Kirdmanee (2009). Proline accumulation, photosynthetic abilities and growth characters of sugarcane (Saccharum offiinarum L.) plantlets in response to isoosmotic salt and water deficit stress. Agric Sci. China., 8(1:51-58.

Duncan, D.B. (1990). Multiple Rang and Multiple F test, Biometrics, 11: 1-24.

El-Sarag, Eman I., A.M. El-Moneim and M.E. Atta (2005). Physiological and morphological studies on fodder beet (Beta vulgaris) under North Sinai conditions, I. Effect of water stress and fertilizers on growth and development of fodder beet. 11th National Conf. Agron. Agric. Fac., Assuit Univ., Egypt, Nov., 2005: 517 - 536.

El-Sarag, Eman I. (2013). Response of fodder beet Cultivars to water stress and nitrogen fertilization in Semi-Arid regions. Ame. Eurasian J. Agric. and Environ. Sci., 13 (9): $1168: 1175$.

Hussein, M.M. and S. Siam (2014). Growth yield and water use efficiency of fodder beet responses to the NPK fertilizer and withholding irrigation. Inter. J. Sci. Res., 3 (11): 3117-3126. 
Ibrahim, Y.M. (2005). Ranges and forage (In Arabic). Dar Azza for publication. Kartoum, Sudan. 300p.

Jafarnia, B., R. Ghorbani, A.Z. Feizabady and A.R. Ghaemi (2013). Impact of crop density and soil fertilization on sugar beet. Inter. $\mathrm{J}$ Agric. Crop Sci., 5 (24): 2991-2999.

Keogh, B.K., P. French, T. Mcgrath, T. Storey and F.J. Mulligan (2008). Effect of forage allowance and forage system during the dry period on the performance of dairy cows. Proc. New Zealand Soc. Anim. Prod., 68: 1619

Khogali, M.E., Y.M., Dagash, Y.M.I., EL-Hag (2011). Productivity of fodder beet (Beta vulgaris var. Crassa) cultivars affected by nitrogen and plant spacing. Agric. Biol. J. N. Ame., 2 (5):791-798.

Kusvuran, S. (2012). Effects of drought and salt stresses on growth, stomatal conductance, leaf water and osmotic potentials of melon genotypes (Cucumls melo L.). Afr. J. Agric. Res., 7(5):775-781.

Larcher, W. (1995). Physiological Plant Ecology. $3^{\text {rd }}$ Ed. Berlin: Springer-Velag.

Leilah, A.A., M.A. Badawi, E.M. Said, M.H. Gonemaand and A.E. Abdou (2005). Effect of planting dates, plant population and nitrogen fertilization on sugar beet productivity under the Newly Reclaimed sandy soils in Egypt. Scien. J. King Faisal Univ., 6 (1):95-110.

Niazi, B.H., J. Rozema, R.A. Broekman and M. Salim (2000). Dynamics of growth and water relations of fodder beet and sea beet in response to salinity. J. Agron. Crop Sci., 184: 101-109.

Parida, A.K. and A.B. Das (2005). Salt tolerance and salinity effects on plants: a review. Ecotoxicol. Environ. Saf., 60: 324-349.

Pearson, C.J., E.M. Larson, J.D. Hesketh and D.B. Peters (1984). Development and sourcesink effects on single leaf and canopy carbon dioxide exchange in maize. Field Crops Res., 9: 391-402.

Pospisil, M., A. Pospisil and M. Rastija (2000). Effect of plant density and nitrogen rates upon the leaf area of seed sugar beet on seed yield and quality. Europ. J. Agron., 12 : 6978.

Souza, G.M., R.F. Oliveira and V.J.M. Cardoso (2004). Temporal Dynamics of stomatal conductance of plants under water deficit: can homeostasis be improved by more complex dynamics?. Brazilian Archives of Biol. Tech. Inter. J., 47(3): 423-431.

Steel, R.G.D. and J.H. Torrie (2000). Principles and Procedures of Statistics, $3^{\text {rd }}$ Ed., McGraw- Hill, N.Y. USA.

Tiryakioglu, H. and M. Turk (2012). Effects of different sowing and harvesting times on yield and quality of forage Turnip (Brassia rapa L.) grown as a second crop. Turkish $\mathrm{J}$. Field Crops, 17(2): 166-170.

Turk, M. (2010). Effect of fertilization on root yield and quality of fodder beet (Beta vulgaris var. crassa mansf.). Bulgarian $\mathrm{J}$. Agric. Sci., 16 (2): 212-219. 


\title{
النشاط الضوئي وعلاقته بإنتاجية بنجر العلف وطرق زراعة وكثافات مختلفة تحت ظروف التربة الرملية
}

\author{
إيمان إسماعيل سعيد السراج \\ قسم الإنتاج النباتىـ كلية العلوم الزر اعية البيئية بالعريش- جامعة العريش اليش ـ مصر
}

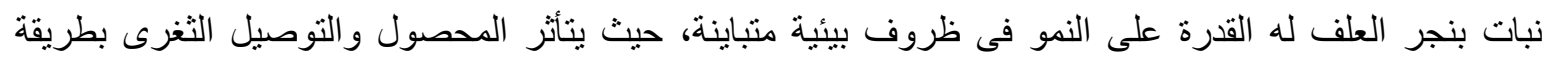

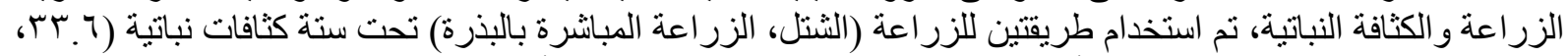

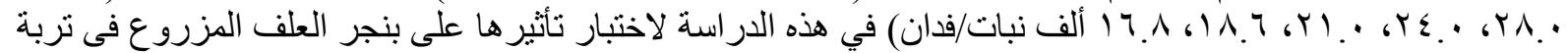

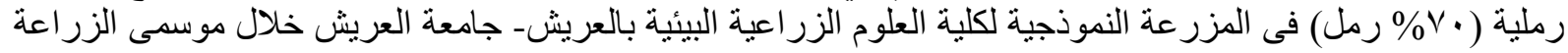

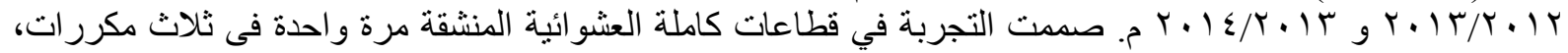

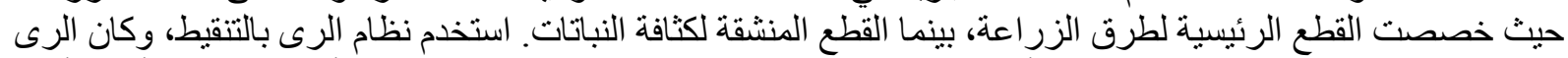

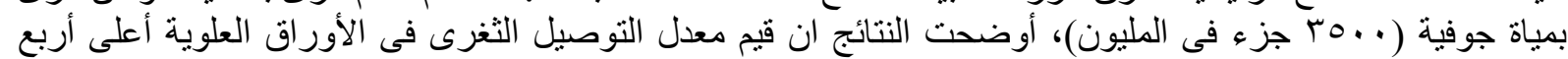

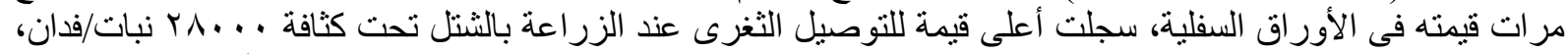

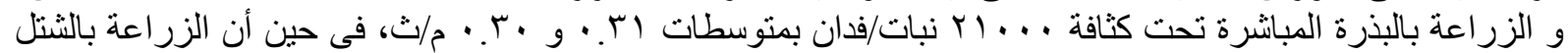

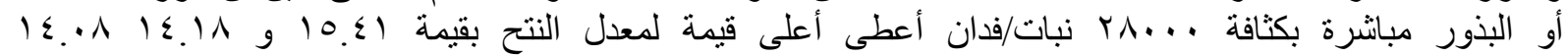

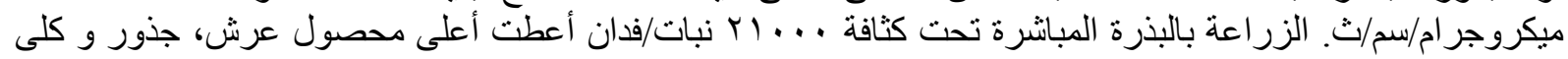

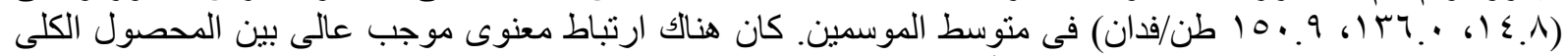

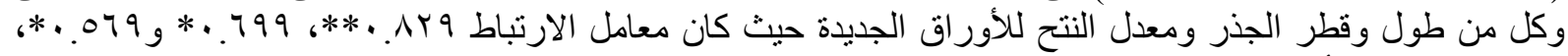

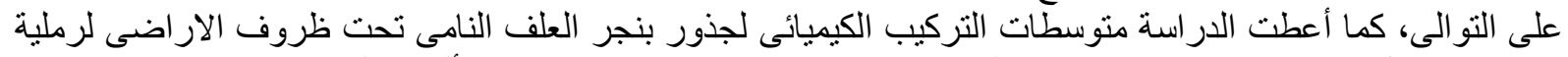

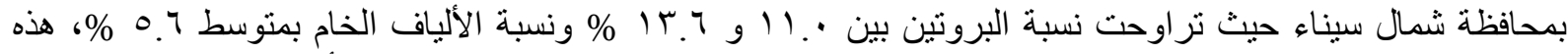

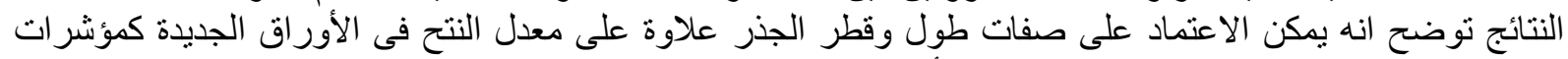

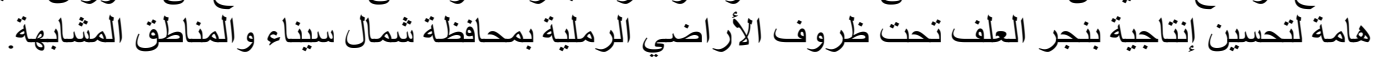

أستاذ ورئيس قسم المحاصبل ـ كلية الزر اعة بالإسماعيلية - جامعة قناة السويس. أستاذ المحاصيل ـ كلية الزر اعة ـ ـ جامعة الزقازيق. 